\title{
Nanosize Copper Dispersed Ionic Liquids As an Electrolyte of New Dye-Sensitized Solar Cells
}

\author{
Fu-Lin Chen, ${ }^{1}$ I.-Wen Sun, ${ }^{1,2}$ H. Paul Wang, ${ }^{2,3}$ and C.-H. Huang ${ }^{3}$ \\ ${ }^{1}$ Department of Chemistry, National Cheng Kung University, Tainan City 701, Taiwan \\ ${ }^{2}$ Sustainable Environment Research Center, National Cheng Kung University, Tainan City 701, Taiwan \\ ${ }^{3}$ Department of Environmental Engineering, National Cheng Kung University, Tainan City 701, Taiwan
}

Correspondence should be addressed to H. Paul Wang, wanghp@mail.ncku.edu.tw

Received 6 October 2008; Accepted 22 January 2009

Recommended by Alan K. T. Lau

To enhance the electrical conductivity of the electrolyte for a newly developed dye-sensitized solar cell (DSSC), metallic copper $(\mathrm{Cu})$ encapsulated within the carbon shell $(\mathrm{Cu} @ \mathrm{C})$ nanoparticles dispersed in a room temperature ionic liquid (RTIL) (e.g., $\left.\left[\mathrm{bmim}^{+}\right]\left[\mathrm{PF}_{6}{ }^{-}\right]\right)$has been studied in the present work. By the pulsed-field gradient spin-echo NMR method, the self-diffusion coefficients of cations and anions of the RTIL have been determined. The self-diffusion coefficient of the [bmim ${ }^{+}$] cations in the RTIL dispersed with 0.08\% of Cu@C nanoparticles is increased by 35\%. The electrical conductivity of the Cu@C dispersed RTIL is also increased by $65 \%(1.0 \rightarrow 2.3 \mathrm{~ms} / \mathrm{cm})$. It is very clear the nanosize Cu@C dispersed RTIL with a relatively greater diffusion coefficient and electrical conductivity can be a very effective electrolyte especially utilized in DSSCs.

Copyright () 2009 Fu-Lin Chen et al. This is an open access article distributed under the Creative Commons Attribution License, which permits unrestricted use, distribution, and reproduction in any medium, provided the original work is properly cited.

\section{Introduction}

Crystalline silicon solar cells have relatively high efficiencies, nevertheless, limited by the high manufacturing cost and long payback period $[1,2]$. On the contrary, organic solar cells have arisen more attentions simply due to the high possibility of creating extremely lightweight, easily integration, low-cost, and flexible solar cells [3]. One of the drawbacks on the performance of dye-sensitized solar cells (DSSCs) is the mediocre stability of the liquid electrolyte in the cells.

Room temperature ionic liquids (RTILs) are of increasing interest and importance in clean industrial processes such as liquid solvents for chemical reactions and extractions and in electrochemical applications as electrolytes for DSSCs, fuel cells and lithium batteries $[4,5]$. Room temperature ionic liquids can also be utilized in gas sensors and biosensors [6]. To increase photovoltaic properties and stability of a DSSC, a composite ionic liquid electrolyte of mixing silica nanoparticles in the 1-methyl-3-propylimidazolium iodide (MPII) has been used to replace the conventional electrolyte [7-9]. An ionic liquid electrolyte containg dispersed carbon nanoparticles, carbon nanotubes, or titatium oxide nanoparticles in the 1-methyl-3-methylimidazolium bis(trifluoromethylsulfonyl) imide had a better photocurrent density and voltage [10].

In the separate experiments, size-controllable $\mathrm{Cu} @ \mathrm{C}$ nanoparticles were synthesized by carbonization of $\mathrm{Cu}^{2+}$ starch or-cyclodextrins complexes at 673-873 K [11]. In the present work, a very small amount of $\mathrm{Cu} @ \mathrm{C}$ nanoparticles with particle sizes as small as $7-20 \mathrm{~nm}$ were dispersed in the RTIL. Their self-diffusion coefficients were determined by pulsed-field gradient spin-echo NMR.

\section{Experimental}

The RTILs were synthesized by the modified procedures reported by Cammarata et al. [12], Tokuda et al. [13, 14] and Yeon et al. [15]. The nanosize $\mathrm{Cu}(7,14$, and $20 \mathrm{~nm}$ in diameter) encapsulated in the carbon shell $(\mathrm{Cu} @ \mathrm{C})$ was obtained by carbonization of the $\mathrm{Cu}^{2+}$-starch complexes at $673 \mathrm{~K}$ for two hours. The ${ }^{1} \mathrm{H}$ NMR chemical shifts and selfdiffusion coefficients were measured using a double-layer tube in which deteriumoxide- $\mathrm{d}_{2}$ (Aldrich) and the sample were filled in the inner tube (closed system) and outer tube, 


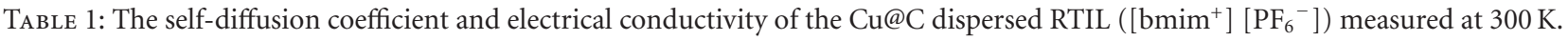

\begin{tabular}{|c|c|c|c|c|c|}
\hline \multirow[t]{2}{*}{$\mathrm{Cu}$ size $(\mathrm{nm})$} & \multirow[t]{2}{*}{$\mathrm{Cu} @ \mathrm{C}(\mathrm{wt} \%)$} & \multicolumn{2}{|c|}{$\begin{array}{l}\text { Self-diffusion coefficients } \\
\qquad\left(10^{-12} \mathrm{~m}^{2} \mathrm{~s}^{-1}\right)\end{array}$} & \multirow[t]{2}{*}{$\begin{array}{l}\text { Electrical conductivity } \\
(\mathrm{ms} / \mathrm{cm})\end{array}$} & \multirow[t]{2}{*}{ Viscosity (cp) } \\
\hline & & {$\left[\mathrm{bmim}^{+}\right]$} & {$\left[\mathrm{PF}_{6}^{-}\right]$} & & \\
\hline & 0 & 5.1 & 5.3 & 2.0 & 178 \\
\hline 7 & 0.08 & 6.4 & 5.5 & 3.1 & 168 \\
\hline 14 & 0.08 & 6.7 & 5.5 & 3.4 & 165 \\
\hline 20 & 0.08 & 6.9 & 5.6 & 3.3 & 164 \\
\hline
\end{tabular}

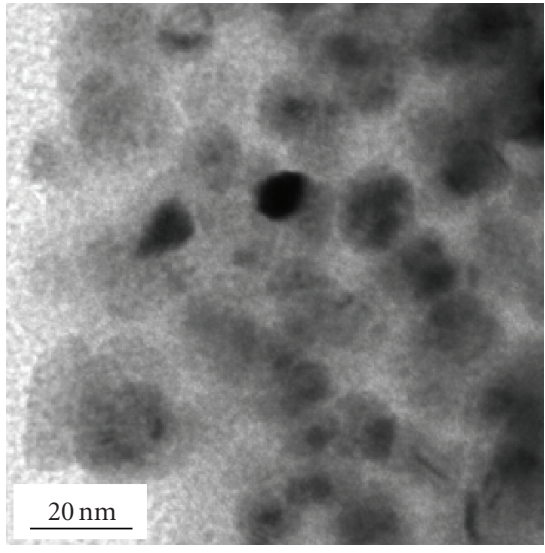

FIGURE 1: The TEM image of the Cu@C (Cu size=14 nm) dispersed in the RTIL $\left(\left[\mathrm{bmim}^{+}\right]\left[\mathrm{PF}_{6}^{-}\right]\right)$.

respectively [16]. Electrolyte conductivities of the Cu@C dispersed RTIL were measured on the Suntex sc-170 at $300 \mathrm{~K}$. Images of the $\mathrm{Cu} @ \mathrm{C}$ dispersed RTIL were also determined by high resolution transmission electron microscopy (TEM) (Philps CM-200).

The K-edge X-ray absorption near edge structure (XANES) and extended X-ray absorption fine structure (EXAFS) spectra of copper in the Cu@C (0.08\%) dispersed RTIL were collected on the Wiggler beam line at the Taiwan National Synchrotron Radiation Research Center. The electron storage was operated at $1.5 \mathrm{GeV}$ (current of 300 $\mathrm{mA}$ ). The beam energy was calibrated by the adsorption edge of a copper foil at energy of $8979 \mathrm{eV}$. The EXAFS data were analyzed using the UWXAFS 3.0 and FEFF 8.0 simulation programs $[17,18]$. The background of the X-ray absorption spectra was justified by the AUTOBK program [17]. The isolated EXAFS data were normalized to the edge jump and converted to the wavenumber scale. The Fourier transform of the spectra was performed on the $k^{3}$-weighted EXAFS oscillations in the range of 3.5 to $11.5 \AA^{-1}$. Empirical fits of model compounds have an error of $\pm 0.01 \AA$ in radius and $\pm 10 \%$ in coordination number $(\mathrm{CN})$ for the first shell atoms.

\section{Results and Discussion}

Table 1 shows the self-diffusion coefficients of the $\left[\mathrm{bmim}^{+}\right]$ cations and $\left[\mathrm{PF}_{6}{ }^{-}\right]$anions in the $\mathrm{Cu} @ \mathrm{C}$ dispersed RTIL determined by ${ }^{1} \mathrm{H}$ and ${ }^{19} \mathrm{~F}$ nuclei NMR spectroscopy at
300. The diffusion coefficient of the $\left[\mathrm{bmim}^{+}\right]$cations in the RTIL dispersed with $0.08 \%$ of $\mathrm{Cu@C} \mathrm{nanoparticles} \mathrm{is}$ increased by $25-35 \%$ if compared with the plain RTIL. Dispersion and insertion of the Cu@C nanoparticles $(\mathrm{Cu}$ sizes $=7-20 \mathrm{~nm}$ ) in the matrix of the RTIL may cause a reduction of the ionic bonding energy between its cations $\left(\left[\mathrm{bmim}^{+}\right]\right)$and anions $\left(\left[\mathrm{PF}_{6}^{-}\right]\right)$, leading to an increase of the self-diffusion coefficient of the $\left[\mathrm{bmim}^{+}\right]$cations from 5.1 to $6.9 \times 10^{-12} \mathrm{~m}^{2} \mathrm{~s}^{-1}$ and a decrease of the RTIL's viscosity from 178 to 164 centipoise (cp). It seems that the $\mathrm{Cu} @ \mathrm{C}$ nanoparticles interact more preferably with the $\left[\mathrm{bmim}^{+}\right]$cations of the RTIL as the self-diffusion coefficient of the $\left[\mathrm{PF}_{6}{ }^{-}\right]$anions influenced by the dispersed $\mathrm{Cu} @ \mathrm{C}$ nanoparticles is relatively insignificant.

In Table 1, in addition to the increase of the self-diffusion coefficients of the $\left[\mathrm{bmim}^{+}\right]$cations in the RTIL dispersed with the $\mathrm{Cu@C} \mathrm{nanoparticles,} \mathrm{an} \mathrm{increase} \mathrm{(up} \mathrm{to} \mathrm{70 \% )} \mathrm{of} \mathrm{the}$ RTIL's electrical conductivity is also found. It is worth noting that the uniform-size $\mathrm{Cu} @ \mathrm{C}$ nanoparticles are well dispersed in the RTIL (see Figure 1). The metallic copper $(\mathrm{Cu})$ having sizes of $7-20 \mathrm{~nm}$ is encapsulated in the carbon shell which is consisted of diamond and graphite carbons with a $\mathrm{sp}^{3} / \mathrm{sp}^{2}$ of $0.5-0.7$ (determined by Raman spectroscopy [11]). The greater electrical conductivity of the ionic liquid electrolyte for the new DSSC may be attributed to the electron-rich carbon shell surfaces of the $\mathrm{Cu@C} \mathrm{nanoparticles} \mathrm{that} \mathrm{interact}$ with the $\left[\mathrm{bmim}^{+}\right]$cations in the RTIL.

Molecular-scale data of $\mathrm{Cu}$ coated with the carbon shell dispersed in the RTIL in terms of the bond distance and coordination number $(\mathrm{CN})$ of near neighbor atoms can be determined by EXAFS spectroscopy. An over 99\% reliability of the EXAFS data fitting for copper species in the RTIL is shown in Table 2. Their Debye-Waller factors are less than 0.01. In the RTIL, $\mathrm{Cu}(7-20 \mathrm{~nm})$ in the $\mathrm{Cu} @ \mathrm{C}$ nanoparticles has $\mathrm{Cu}-\mathrm{Cu}$ bond distances of $2.530-2.535 \AA$, and its CNs increase from 6.2 to 8.7 as the $\mathrm{Cu}$ sizes increase.

Figure 2 shows the XANES spectra of copper in the $\mathrm{Cu} @ \mathrm{C}$ nanoparticles dispersed RTIL. Their preedge XANES spectra exhibit a very weak 1s-to-3d transition (8975$8980 \mathrm{eV}$ ) which is forbidden by the selection rule in the case of perfect octahedral symmetry. A shoulder at (8984$8988 \mathrm{eV})$ and an intense band at $(8995-9002 \mathrm{eV})$ is due to the $1 \mathrm{~s}$ to $4 \mathrm{p}$ transition that indicates the existence of the $\mathrm{Cu}$ (II) species. The XANES spectrum of copper in the $\mathrm{Cu} @ \mathrm{C}$ is very similar to that in the $\mathrm{Cu} @ \mathrm{C}$ dispersed in the RTIL. Nevertheless, about $11 \%$ of $\mathrm{Cu}$ originally in the core of the core-shell Cu@C nanoparticles (dispersed in the RTIL) is 
TABLE 2: Structure parameters of copper in the Cu@C $(0.08 \%)$ dispersed RTIL $\left(\left[\mathrm{bmim}^{+}\right]\left[\mathrm{PF}_{6}^{-}\right]\right)$.

\begin{tabular}{llcll}
\hline Size $(\mathrm{nm})$ & Shell & Bond distance $(\AA)$ & $\begin{array}{l}\text { Coordination } \\
\text { number }\end{array}$ & $\begin{array}{l}\text { Dybe-Weller } \\
\text { factor }\left(\sigma^{2}\right)\end{array}$ \\
\hline 7 & $\mathrm{Cu}-\mathrm{Cu}$ & 2.533 & 6.2 & 0.0079 \\
14 & $\mathrm{Cu}-\mathrm{Cu}$ & 2.535 & 6.3 & 0.0081 \\
20 & $\mathrm{Cu}-\mathrm{Cu}$ & 2.530 & 8.7 & 0.0075 \\
\hline
\end{tabular}

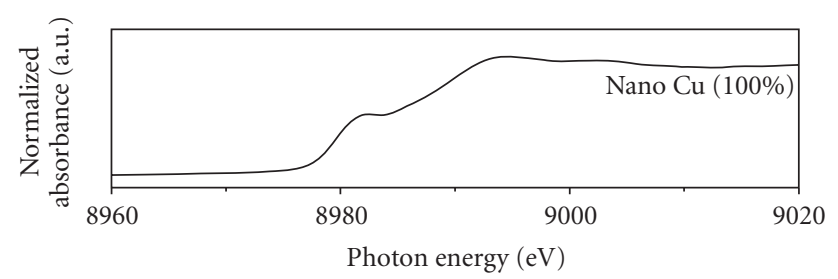

(a)

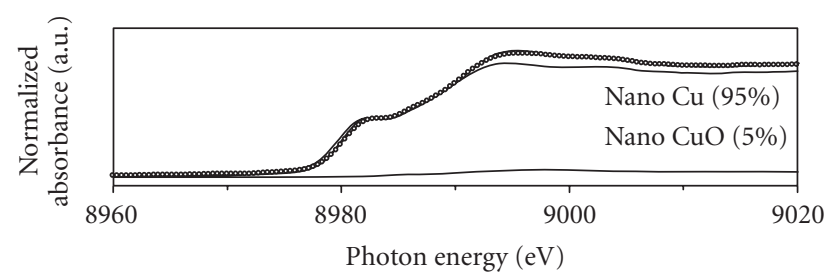

(b)

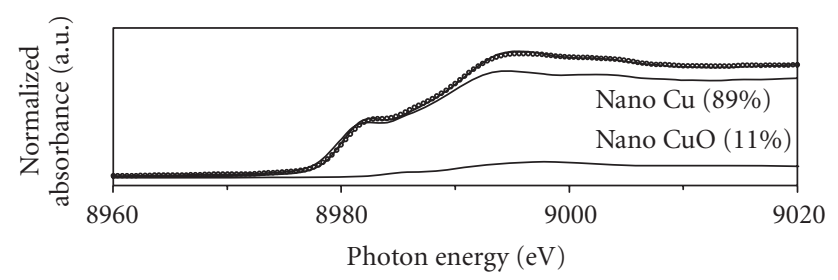

(c)

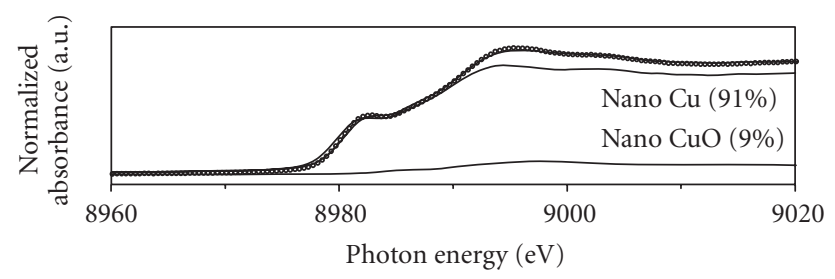

(d)

FIgure 2: The least-square fitted XANES spectra of copper in (a) nanosize $\mathrm{Cu}$ and $\mathrm{Cu} @ \mathrm{C}(0.08 \%)$ having $\mathrm{Cu}$ sizes of (b) 7, (c) 14, and (d) $20 \mathrm{~nm}$ dispersed in the RTIL $\left(\left[\mathrm{bmim}^{+}\right]\left[\mathrm{PF}_{6}{ }^{-}\right]\right)$.

oxidized to $\mathrm{CuO}$. Note that the fraction of surface $\mathrm{Cu}$ atoms to the total atoms for the $\mathrm{Cu}$ nanoparticle having a size of $7 \mathrm{~nm}$ is $11 \%$. It is very likely that in the RTIL the encapsulated $\mathrm{Cu}$ may involve in oxidation with residual oxygen in the RTIL on the surfaces of the $\mathrm{Cu}$ nanoparticles. The $\mathrm{CuO}$ layer on the surfaces of the core $\mathrm{Cu}$ in the $\mathrm{Cu} @ \mathrm{C}$ may also facilitate the electron transport limited to the surfaces of the carbon shell for a better efficiency.

\section{Conclusion}

Dispersion of a very small amount (0.08\%) of $\mathrm{Cu} @ \mathrm{C}$ nanoparticles in the RTIL can increase the diffusion coefficient of the cations in the RTIL by 35\%. The diffusion coefficient of the anions in the $\mathrm{Cu} @ \mathrm{C}$ dispersed RTIL is relatively less influenced. An increase (up to 70\%) of the Cu@C dispersed RTIL's electrical conductivity is also found. The greater electrical conductivity of the ionic liquid electrolyte for the new DSSC may be attributed to the electron-rich carbon shell surfaces of the $\mathrm{Cu@C} \mathrm{nanoparticles} \mathrm{that} \mathrm{interact}$ with the $\left[\mathrm{bmim}^{+}\right]$cations in the RTIL. The CuO layer on the surfaces of the core Cu in the Cu@C may also facilitate the electron transport limited to the surfaces of the carbon shell for a better efficiency.

\section{Acknowledgments}

This research was supported by the Taiwan National Science Council, Bureau of Energy, and the Excellence Project of the National Cheng Kung University. We thank J. F. Lee and Y. M. Yang of the Taiwan Synchrotron Radiation Research Center (SRRC) for their EXAFS experimental assistances. The beam time provided by the SRRC is also appreciated.

\section{References}

[1] G. G. Wallace, P. C. Dastoor, D. L. Officer, and C. O. Too, "Conjugated polymers: new materials for photovoltaics," Chemical Innovation, vol. 30, no. 4, pp. 14-22, 2000.

[2] J. Chen, D. L. Officer, J. M. Pringle, D. R. MacFarlane, C. O. Too, and G. G. Wallace, "Photoelectrochemical solar cells based on polyterthiophenes containing porphyrins using ionic liquid electrolyte," Electrochemical and Solid-State Letters, vol. 8, no. 10, pp. A528-A530, 2005.

[3] B. O’Regan and M. Grätzel, "A low-cost, high-efficiency solar cell based on dye-sensitized colloidal $\mathrm{TiO}_{2}$ films," Nature, vol. 353, no. 6346, pp. 737-740, 1991.

[4] N. Papageorgiou, Y. Athanassov, M. Armand, et al., "The performance and stability of ambient temperature molten salts for solar cell applications," Journal of the Electrochemical Society, vol. 143, no. 10, pp. 3099-3108, 1996.

[5] H. Matsumoto, T. Matsuda, T. Tsuda, R. Hagiwara, Y. Ito, and Y. Miyazaki, "The application of room temperature molten salt with low viscosity to the electrolyte for dye-sensitized solar cell," Chemistry Letters, vol. 30, no. 1, p. 26, 2001.

[6] S.-F. Ding, M.-Q. Xu, G.-C. Zhao, and X.-W. Wei, "Direct electrochemical response of Myoglobin using a room temperature ionic liquid, 1-(2-hydroxyethyl)-3-methyl imidazolium tetrafluoroborate, as supporting electrolyte," Electrochemistry Communications, vol. 9, no. 2, pp. 216-220, 2007.

[7] F. Zhaofu, K. Daibin, Z. Dongbin, et al., "A supercooled imidazolium iodide ionic liquid as a low-viscosity electrolyte for dye-sensitized solar cells," Inorganic Chemistry, vol. 45, no. 26, pp. 10407-10409, 2006.

[8] W. Ning, L. Honge, L. Jianbao, and L. Xin, "Improved quasisolid dye-sensitized solar cells by composite ionic liquid electrolyte including layered $\alpha$-zirconium phosphate," Applied Physics Letters, vol. 89, no. 19, Article ID 194104, 3 pages, 2006.

[9] K. Daibin, W. Peng, I. Seigoe, and M. Grätzel, "Stable mesoscopic dye-sensitized solar cells based on tetracyanoborate 
ionic liquid electrolyte," Journal of the American Chemical Society, vol. 128, no. 24, pp. 7732-7733, 2006.

[10] H. Usui, H. Matsui, N. Tanabe, and S. Yanagida, "Improved dye-sensitized solar cells using ionic nanocomposite gel electrolytes," Journal of Photochemistry and Photobiology A, vol. 164, no. 1-3, pp. 97-101, 2004.

[11] C.-H. Huang, H. Paul Wang, and C.-Y. Liao, "Nanosize Copper Encapsulated Carbon Thin Films on a Dye-sensitized Solar Cell Cathode," Journal of Nanoscience and Nanotechnology, 2009, (in press).

[12] L. Cammarata, S. G. Kazarian, P. A. Salter, and T. Welton, "Molecular states of water in room temperature ionic liquids," Physical Chemistry Chemical Physics, vol. 3, no. 23, pp. 51925200, 2001.

[13] H. Tokuda, K. Hayamizu, K. Ishii, Md. A. B. Hasan-Susan, and M. Watanabe, "Physicochemical properties and structures of room temperature ionic liquids. 1. Variation of anionic species," Journal of Physical Chemistry B, vol. 108, no. 42, pp. 16593-16600, 2004.

[14] H. Tokuda, K. Hayamizu, K. Ishii, Md. A. B. Hasan-Susan, and M. Watanabe, "Physicochemical properties and structures of room temperature ionic liquids. 2. Variation of alkyl chain length in imidazolium cation," Journal of Physical Chemistry B, vol. 109, no. 13, pp. 6103-6110, 2005.

[15] S.-H. Yeon, K.-S. Kim, S. Choi, H. Lee, H. S. Kim, and H. Kim, "Physical and electrochemical properties of 1-(2-hydroxyethyl)-3-methyl imidazolium and $\mathrm{N}$-(2hydroxyethyl)- $N$-methyl morpholinium ionic liquids," Electrochimica Acta, vol. 50, no. 27, pp. 5399-5407, 2005.

[16] H. Tokuda, S. Tsuzuki, Md. A. B. Hasan-Susan, K. Hayamizu, and M. Watanabe, "How ionic are room-temperature ionic liquids? An indicator of the physicochemical properties," Journal of Physical Chemistry B, vol. 110, no. 39, pp. 1959319600, 2006.

[17] A. L. Ankudinov, B. Ravel, J. J. Rehr, and S. D. Conradson, "Real-space multiple-scattering calculation and interpretation of X-ray-absorption near-edge structure," Physical Review B, vol. 58, no. 12, pp. 7565-7576, 1998.

[18] E. A. Stern, M. Newville, B. Ravel, Y. Yacoby, and D. Haskel, "The UWXAFS analysis package: philosophy and details," Physica B, vol. 208-209, pp. 117-120, 1995. 

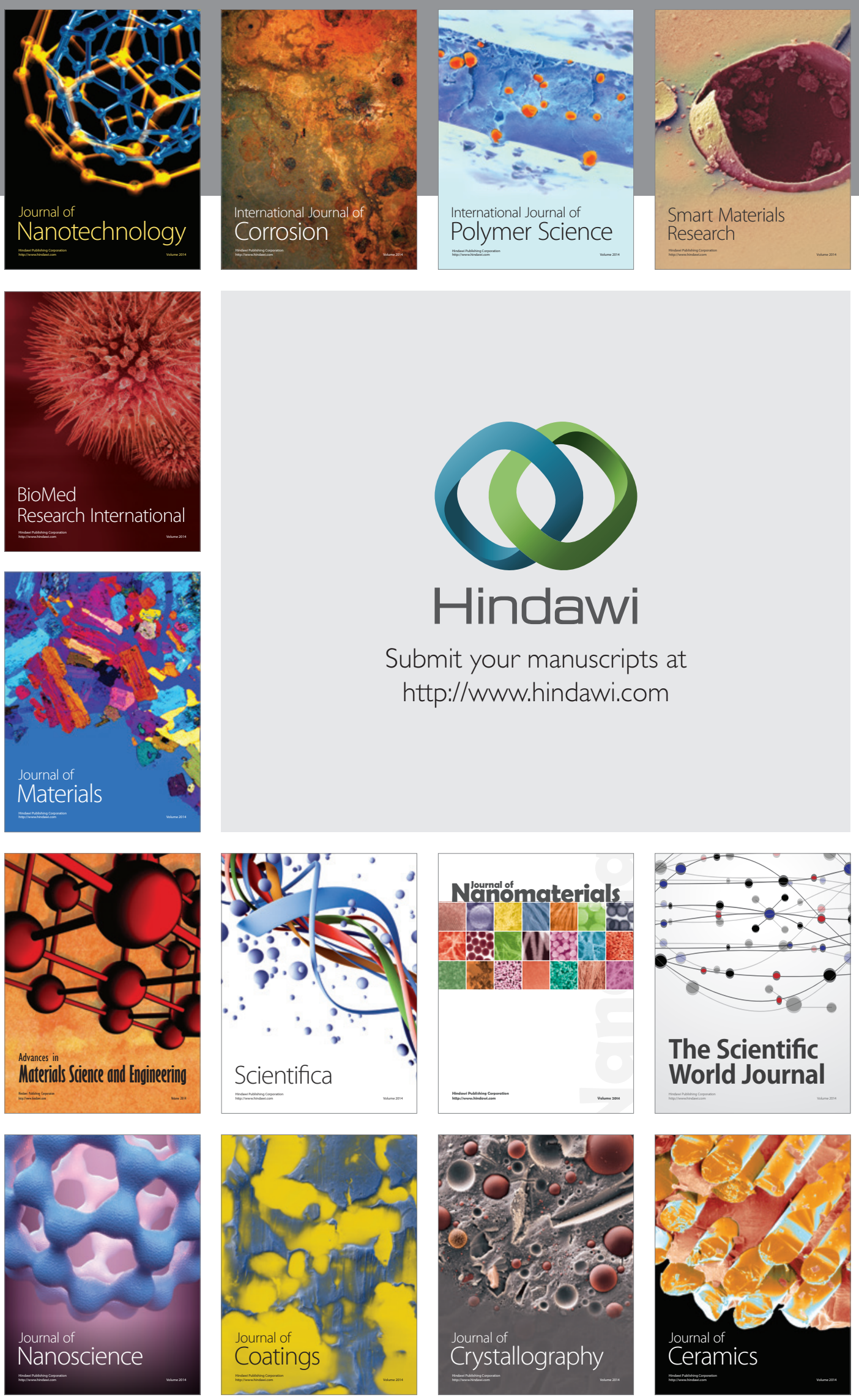

The Scientific World Journal

Submit your manuscripts at

http://www.hindawi.com

\section{World Journal}

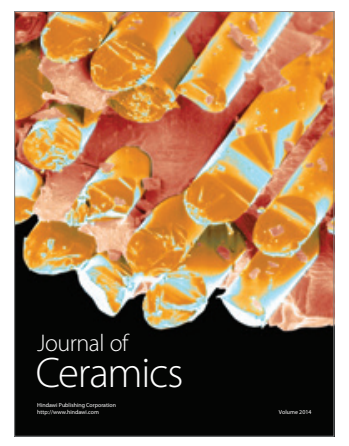

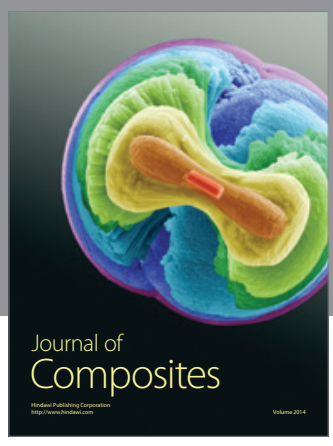
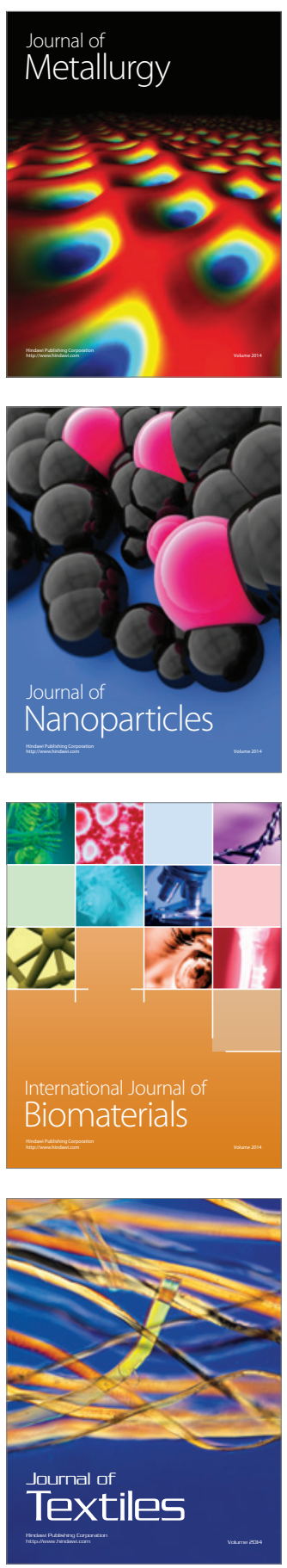